\title{
THE LIFE HISTORY OF THE JAPANESE CARRION BEETLE PTOMASCOPUS MORIO AND THE ORIGINS OF PARENTAL CARE IN NICROPHORUS (COLEOPTERA, SILPHIDAE, NICROPHORINI).*
}

\author{
By Stewart B. Peck \\ Department of Biology, Carleton University, \\ Ottawa, Ontario, K1S 5B6, Canada
}

\section{INTRODUCTION}

The subject of the origin and evolution of sociality in insects has a rapidly growing literature. Most of this pertains to the Hymenoptera. Within the Coleoptera, presocial or subsocial parental care and division of labor are known in at least nine families (Wilson, 1971). The most advanced form of parental care known in beetles is that of the Nicrophorus carrion or burying beetles (tribe Nicrophorini). This generalization is based on the study of six European species by Pukowski $(1933,1934)$ which has since been abstracted and popularized by many (e.g., Balduf, 1935; Milne and Milne, 1944, 1976; Wilson, 1971, 1975). Briefly, a male and female form a conspecific pair at a carcass of a mouse or other small vertebrate. They work cooperatively to exclude eompetitors, to bury the carcass, and to shape it into a ball in a crypt. The male leaves after oviposition but the female tends the developing larvae, calling them to the carrion by stridulation, and repeatedly feeds them by regurgitation. Such behaviors do not exist in the other tribe of silphid carrion beetles, the Silphini.

The only work on the life cycle of a North American Nicrophorus is a short note by Leech (1934) on $N$. defodiens (under the name $N$. conversator). Thus, it is not really known how general or widespread is the phenomenon of parental care in the genus, nor if all species are equally advanced behaviorally. There are about 20 species in the New World, and at least 65 species in all the world, in several lineages within the genus.

As part of a series of studies on the comparative biology and evolution of silphid beetles, I undertook a study of the life history of Ptomascopus morio Kraatz of Japan, to learn something of the

*Manuscript received by the editor October 29, 1981. 
origin of parental care in Nicrophorus. Ptomascopus is the only other genus in the tribe Nicrophorini and contains only two Asian species, $P$. morio being more common and widespread than $P$. plagiatus Menetries (Hlisnikowski, 1942). It is illustrated in many general Japanese insect books such as Esaki et al. (1932, 1956), Nakane et al. (1963), and Nakane (1980). The larvae are illustrated by K. Kurosa in Kawada (1959).

The genus shares with Nicrophorus many derived morphological characters relative to the Silphini: adults with stridulatory files, reduced second antennal segment, fused gular sutures, sexually dimorphic membranous anticlypeus; larvae with abdominal paranotal projections and cuticular sclerotization reduced, and with only one pair of ocelli.

The main morphological characters in which Ptomascopus is more primitive than Nicrophorus are in its possession of a normally clavate antennal club, rather than with a strongly capitate club formed from the last four segments, and in its less fossorial tibiae.

\section{Methods AND Materials}

Four pairs of $P$. morio were collected in August, 1980, at carrion baits in a warm-temperate mixed mesophytic forest in the Omogo Valley of Mount Ischizuchi Quasi-National Park, Shikoku, Japan. They were brought to Ottawa, Canada, and placed in culture at $18^{\circ} \mathrm{C}$, with a normal daylight regime, from September to December. The pairs were kept in separate seven $\mathrm{cm}$ deep boxes of clear plastic, floored with five $\mathrm{cm}$ of coarse damp sand. Two $\mathrm{cm}$ cubes of chicken neck were given as carrion food at required intervals. Observations were made daily. The data gained are variable in quantity and quality and are usually not abundant enough for tests of significance. Only simple means, sample sizes, and ranges are reported, but these are sufficient for comparative purposes.

\section{RESULTS}

Both sexes dug irregular tunnels in the sand but not in direct association with the carrion. Most of their time was spent in these tunnels. They fed at the carrion and sporadically dug under it, but there was no direct indication of digging with the intention of burying the food, or of manipulating the food into a food ball, or of forming a crypt for it. Mating was observed occasionally but no indication of a courtship ritual was noted. 
Eggs were laid singly in the sand several $\mathrm{cm}$ to the side of the carrion. A mean of 13 eggs $(\mathrm{N}=9, \mathrm{r}=9-16)$ were laid per female in 6 days $(\mathrm{N}=9, \mathrm{r}=5-8)$, and a new clutch was started after a refractory period of 6 more days $(N=8, r=5-8)$. The eggs hatched in 5 days $(N=30, r=4-7)$. Frequent adult attempts to fly and leave the culture containers after the egg clutch was laid may indicate that post-mating (for the male) or post-oviposition dispersal is normal, and that the adults are normally not present with their young.

The larvae fed together under and directly on the carrion. There was no indication of parental attendance to, or feeding of, the larvae. The adults and larvae may feed on fly larvae or other insects associated with carrion in nature, but carrion alone is adequate for complete development of larvae in culture. There were 3 larval instars; the first lasted 1 day $(N=30, r=1-2)$, the second 2 days $(\mathrm{N}=30, \mathrm{r}=2-3)$. The third instar larvae fed for 7 days $(\mathrm{N}=30$, $r=6-9$ ) before crawling away from the carrion and burrowing into the sand to form pupal cells. In total, over 300 larvae were produced, of which about 50 were preserved for morphological study.

Prepupae had a high mortality due to a fungal contamination. The prepupal phase seems to be about 30 days in duration $(\mathrm{N}=7$, $r=28-40$ ). The pupal phase also seems to last about another 30 days before emergence of the adult $(\mathrm{N}=2, \mathrm{r}=25-35)$. At culture temperatures the parental generation adults died by early December, for a longevity of at least four months. This could be considerably different in the field depending on their sensitivity to cool fall temperatures and whether or not they overwinter as adults.

\section{Discussion}

There was no indication of any subsocial or other behavioral association between the larvae and the adults as known in Nicrophorus. The brood size, reduced fecundity, and shorter larval developmental times are similar to those reported in Nicrophorus, but otherwise the life cycle characteristics are generally similar to those reported for the carrion-feeding Silphini (Balduff, 1935; Brewer and Bacon, 1975; Cole, 1942; Cooley, 1917; and Ratcliffe, 1972). It should be noted that some Silphines appear to have derived feeding characteristics, being strict predators and phytophages. How this may have changed behavior and life cycle characteristics is not known. 
The results were verified by Dr. Kazuyoshi Kurosa of Tokyo (pers. comm.) who reared the beetle some 30 years ago in Oita Prefecture, Japan, but did not publish the results. He found no parental care, no sign of burying the food, and no parental attendance on the larvae, which grew well on fresh beef. Still, further observations with a natural forest soil substrate and natural food items like mouse or shrew carcasses would be desirable. How the beetles survive and "partition resources" in the face of what seemed to me to be severe competition from the diverse fauna of Japanese carrion beetles remains unknown.

\section{Conclusions}

It appears that the origin of parental care of larvae did not occur in an ancestor common to Ptomascopus and Nicrophorus, but seemingly in Nicrophorus itself, after the differentiation of the genus. If the origin was sometime after that of the genus itself we may expect a wider range of parental care and related behaviors in Nicrophorus than is generally assumed in the recent literature on these beetles. A greater number of Nicrophorus species should be studied to investigate the questions of the origin and evolution of sub-sociality within the genus, and the results should be evaluated with reference to a cladistic (phylogenetic) analysis of the evolution of morphological characters.

\section{ACKNOWLEDGMENTS}

I thank Dr. Shun-Ichi Ueno of Tokyo and Dr. Kazuo Ishikawa of Matsuyama for making my Japanese field work possible and exceptionally informative. Field support was from operating grants of the Canadian Natural Sciences and Engineering Research Council. The manuscript was read and helped by comments from R.S. Anderson, A.F. Newton, K. Kurosa, R.B. Madge, and D.S. Wilson.

\section{Literature Cited}

Balduf, W. V.

1935. The bionomics of entomophagous Coleoptera. J. S. Swift Co., St. Louis. 220 pp. Reprinted in 1969 by E. W. Classey, Hampton, England.

BREWER, J. W. AND T. R. BACON

1975. Biology of the carrion beetle Silpha ramosa Say. Ann Entomol Soc Am 68: $786-790$. 
Cole, A. C., JR.

1942. Observations of three species of Silpha (Coleoptera: Silphidae). Am Midl Nat 28: 161-163.

CoOley, R. A.

1917. The spinach carrion beetle. J Econ Entomol 10: 94-102.

Esaki, T., H. Hori, S. Hozawa.

1932. Iconographia Insectorum Japonicorum. Hokuryukan, Tokyo. 4404 pp.

Esaki, T., T. Ishit, T. Kawamura.

1956. Iconographic Insectorum Japonicorum. Editio Secunda, Reformata. Hokuryukan, Ltd., Tokyo. $1737+203$ pp.

HLISNIKOWSKI, J.

1942. Coleopterologische Notizen. Mitteil Münchner Entomol Gesells 32: 578-579.

KaWADA, A.

1959. Illustrated Insect Larvae of Japan. Hokuryukan Co., Ltd., Tokyo. 712 $\mathrm{pp}+$ indexes.

LEECH, H. B.

1934. The family history of Nicrophorus conversator Walker. Proc British Columbia Entomol Soc 1934: 36-40.

Milne, L. J. And M. J. Milne

1944. Notes on the behavior of burying beetles (Nicrophorus spp.). J New York Entomol Soc 52: 311-327.

Milne, L. J. ANd M. J. Milne

1976. The social behavior of burying beetles. Scientific American, 235: 84-89.

Nakane, T., K. Ohbayshi, S. Nomura, and Y. Kurosawa

1963. Iconographic Insectorum Japonicorum, Colore naturali edita, Volumen II (Coleoptera). Hokuryukan, Tokyo. 443 pp.

NAKANE, T.

1980. Coloured illustrations of the insects of Japan, vol. I, Coleoptera. Enlarged and revised, edited by the Japan Coleopterological Society. Hoikusha Pub., Osaka. 275 pp.

Pukowski, E.

1933. Okologische Untersuchungen an Necrophorus F. Zeit Okol Morph Tiere 27: $518-586$.

Pukowski, E.

1934. Die Brutpflege des Totengrabers. Entomol Blätter 30: 109-113.

RATCliffe, B. C.

1972. The natural history of Necrodes surinamensis (Fabr.) (Coleoptera: Silphidae). Trans Am Entomol Soc 98: 359-410.

WILSON, E. O.

1971. The Insect Societies. Belknap Press, Harvard University Press, Cambridge, Mass. $548 \mathrm{pp}$.

WILSON, E. O.

1975. Sociobiology, the new synthesis. Belknap Press, Harvard University Press, Cambridge, Mass. 697 pp. 

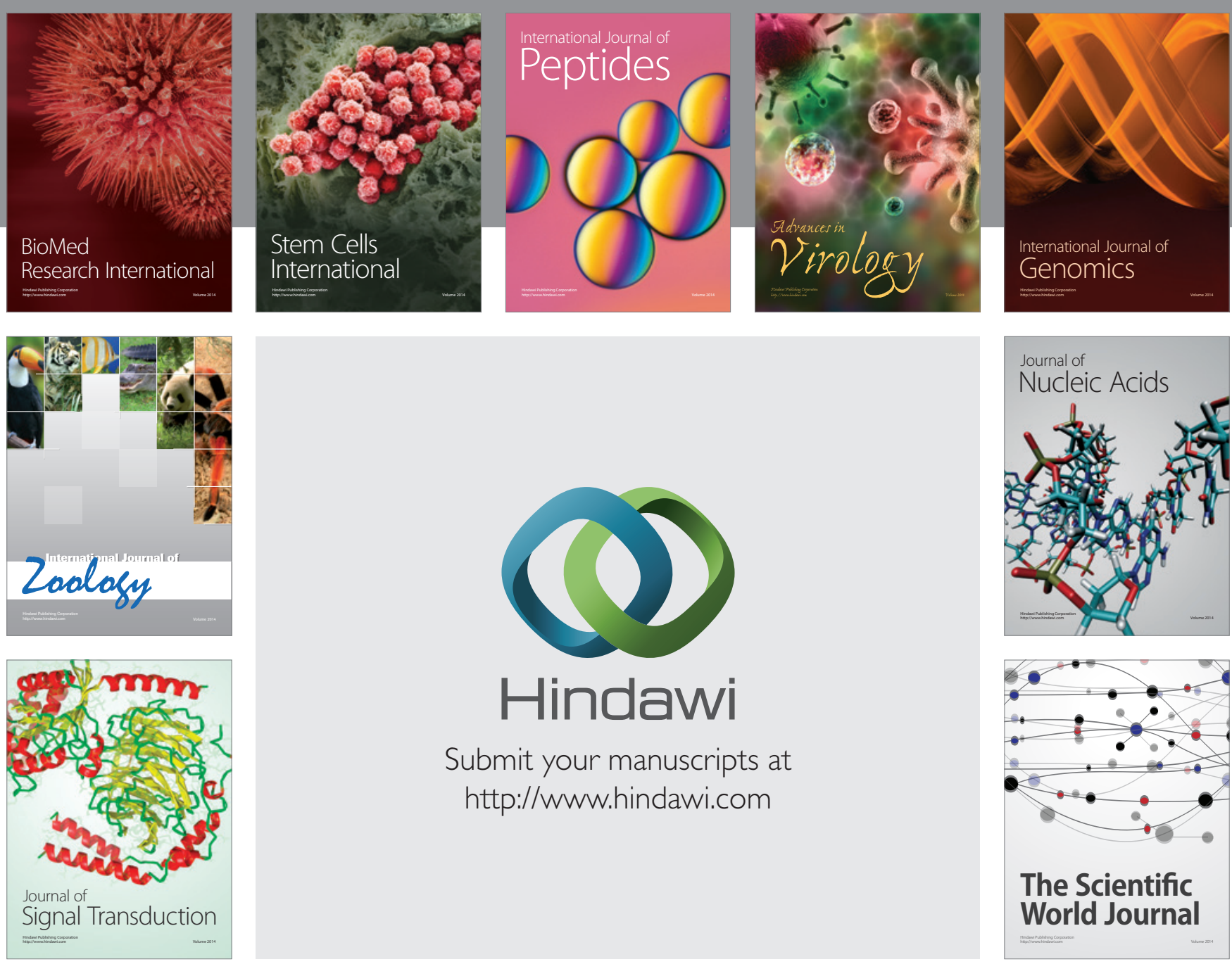

Submit your manuscripts at

http://www.hindawi.com
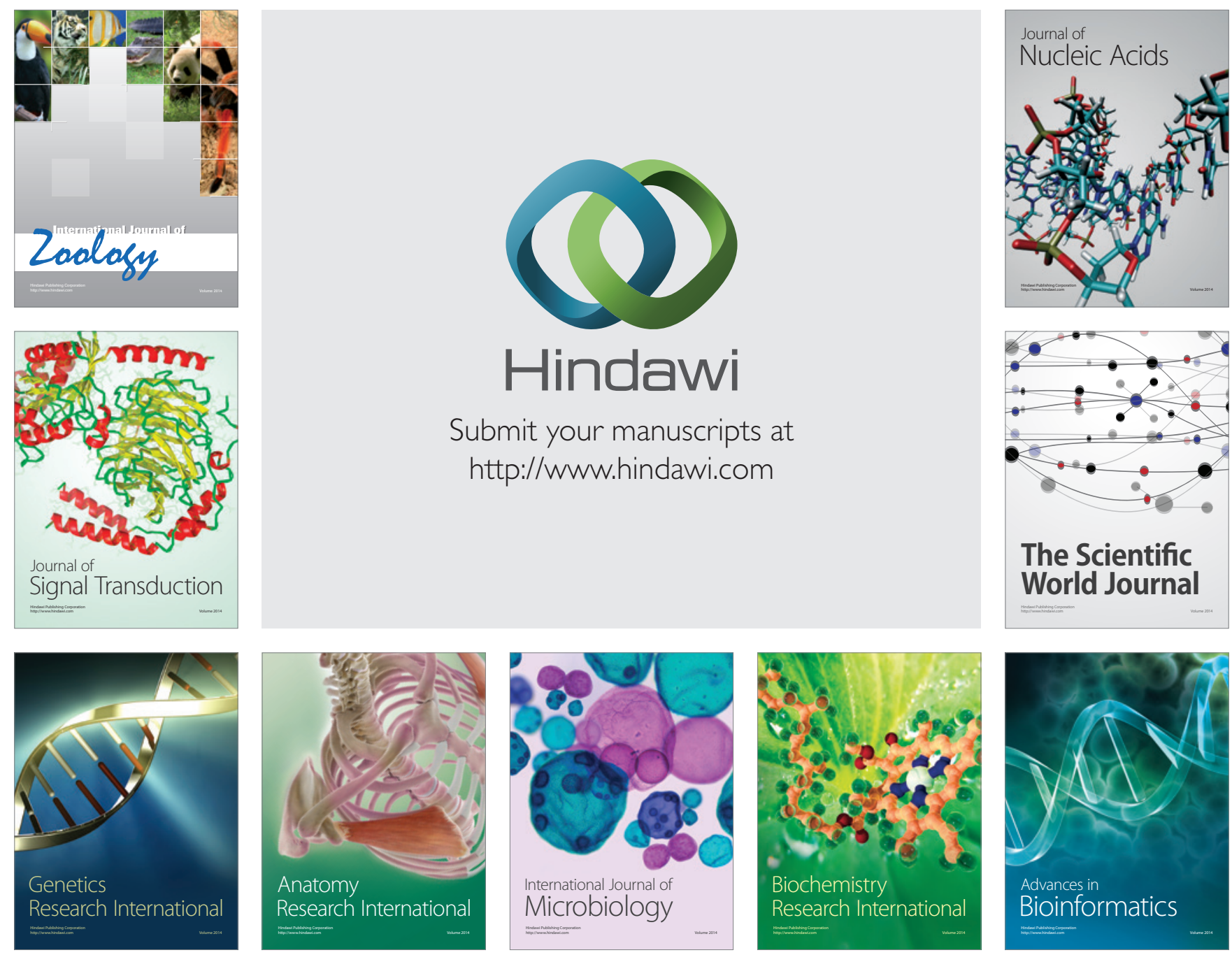

The Scientific World Journal
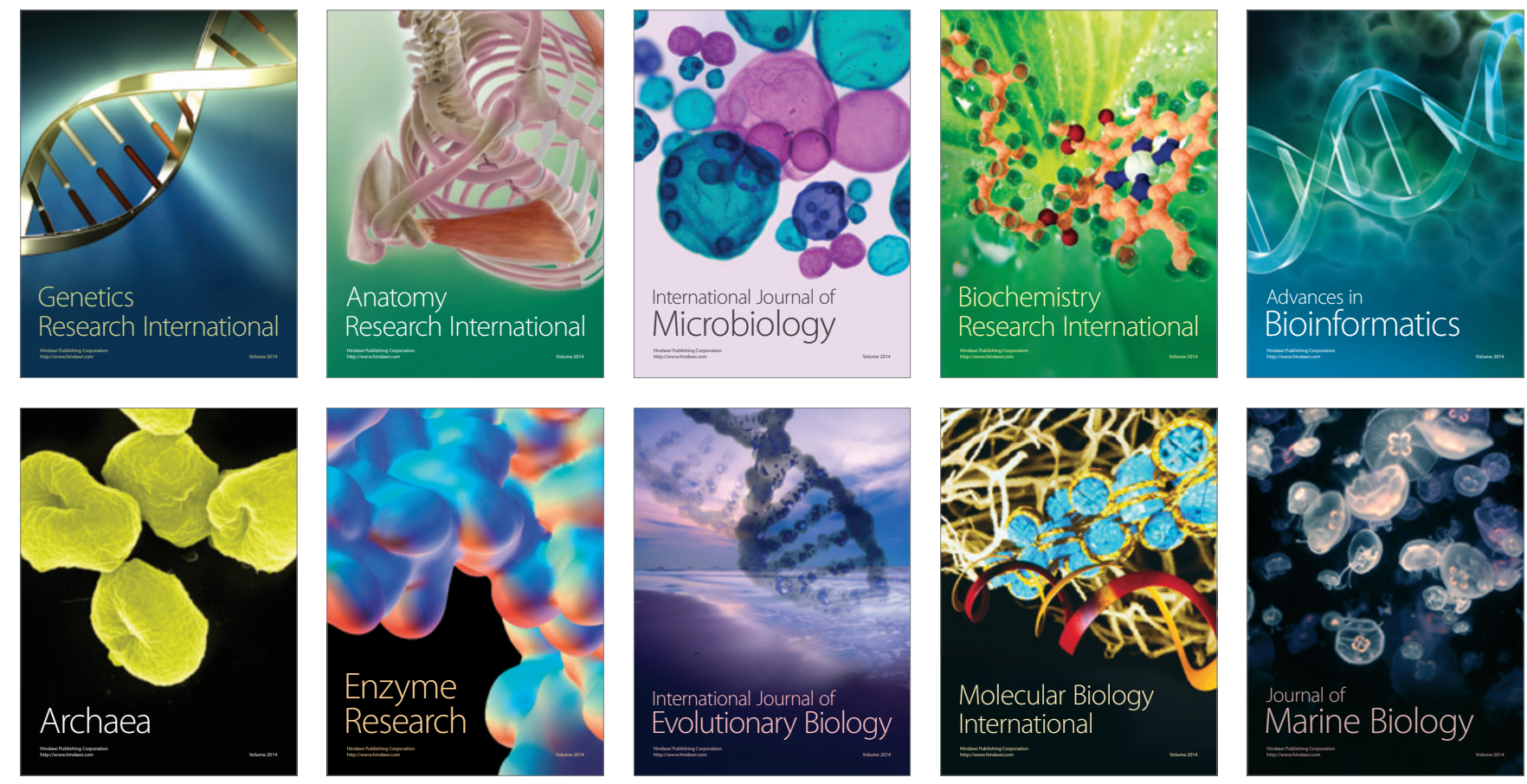